\title{
Clearing islands as refugia for black-fronted tern (Chlidonias albostriatus) breeding colonies in braided rivers
}

\author{
Ann-Kathrin V. Schlesselmann ${ }^{1 *}$, Colin F.J. O’Donnell ${ }^{2}$, Joanne M. Monks ${ }^{3}$ and \\ Bruce C. Robertson ${ }^{1}$ \\ ${ }^{1}$ Department of Zoology, University of Otago, PO Box 56, Dunedin 9054, New Zealand \\ ${ }^{2}$ Biodiversity Group, Department of Conservation, Private Bag 4715, Christchurch 8140, New Zealand \\ ${ }^{3}$ Biodiversity Group, Department of Conservation, PO Box 5244, Dunedin 9058, New Zealand \\ *Author for correspondence (Email: a.schlesselmann@postgrad.otago.ac.nz)
}

Published online: 25 June 2018

\begin{abstract}
Black-fronted terns/tarapirohe (Chlidonias albostriatus) are highly adapted to nesting on clear shingle areas of the braided rivers in the South Island, New Zealand. They are nationally and internationally classified as 'Endangered'. Ongoing threats, primarily an interaction of predation and habitat degradation or loss, have resulted in population decline. Conservation management in the form of control of introduced mammalian predators has proven partially successful. Using the lower Waitaki River as a case study, we cleared vegetation from seven islands creating potential refugia from mammalian predators and providing high quality bare gravel breeding habitat. We: (1) determined the mammalian predators present on river banks, vegetated islands and cleared islands; (2) assessed the nesting success of black-fronted terns and primary causes of nest failure; (3) identified the predator species at nests using remote cameras; and (4) compared the nesting success on cleared and vegetated islands. Fewer mammalian predators were detected on islands compared to adjacent riverbanks: mustelids (Mustela spp.) occurred on approximately half of the vegetated islands, but only mice (Mus musculus) were detected once on one of the cleared islands. Black-fronted terns established three colonies on islands immediately after the clearing of vegetation, but nesting success in the lower Waitaki River was low overall $(50.5 \%$ to $56.4 \%$ of nests contained at least one egg that hatched) and the primary cause of nest failure was predation before and after clearing islands. The main predators of nests $(62.5 \%$ of predation events $)$ were southern black-backed gulls (Larus dominicanus). There was no overall difference in nesting successes of colonies between cleared and vegetated islands, presumably because gulls depredated tern eggs irrespective of vegetation cover around target nests. Nesting success depended on the timing and size of the colony, with earlier established nests and nests in larger colonies being more successful. Artificially created nesting habitat can play a critical role for conservation, particularly on lowland rivers in New Zealand, and we recommend control of avian predators be considered.
\end{abstract}

Keywords: nesting success; enhancement; gull predation; management; modification; nesting habitat; vegetation; weeds

\section{Introduction}

Black-fronted terns/tarapirohe (Chlidonias albostriatus) are endemic to New Zealand, breed only in the braided rivers of the South Island and migrate to the coast during winter (Higgins \& Davies 1996; Schlesselmann et al. 2017). They form loose breeding colonies sometimes re-using the same breeding site in catchments (Keedwell 2005; Bell2017). Similar to other marsh terns (genus Chlidonias), they specialise on using unstable and ephemeral breeding habitat, and are able to respond to changes in the environment quickly (Higgins \& Davies 1996). They are currently classified nationally and internationally as 'Endangered' as population declines of around $50 \%$ over the next 30 years are predicted (O’Donnell \& Hoare 2011; BirdLife International 2017; Robertson et al. 2017).

Their decline in population size is thought to be the product of multiple threats, primarily associated with habitat loss and increased risk of predation leading to low recruitment. An increasing demand for water abstraction for irrigation and diversion, and impoundment for hydroelectric power generation, has led to significantly reduced water flows in many braided rivers (Ministry for the Environment \& Stats
NZ 2017). Invasive alien plant species now dominate braided river beds, making areas unavailable to breeding black-fronted terns and other braided river avian specialists such as wrybill (Anarhynchus frontalis) and black-billed gulls (Larus bulleri) (Maloney et al. 1999; Williams \& Wiser 2004; McClellan 2009; O’Donnell et al.2016). Introduced mammalian predators (e.g. feral cats (Felis catus), stoats (Mustela erminea), ferrets (Mustela furo) and hedgehogs (Erinaceus europaeus)) are a primary cause of mortality in adults, chicks, and eggs (Sanders \& Maloney 2002; Keedwell et al. 2002; Cruz et al. 2013; Bell 2017). In addition, native avian predators like the Australasian harrier (Circus approximans) and the southern black-backed gull (Larus dominicanus) have increased in abundance since the arrival of Europeans in New Zealand in the $19^{\text {th }}$ century (Turbott 1967). These species prey upon eggs and chicks of native braided river birds (Sanders \& Maloney 2002; Steffens et al.2012). The colonial nesting habit also makes black-fronted terns more vulnerable to localised events, e.g. catastrophic failure of nests often occurs due to flooding of a whole colony site or predation events of a few nests can lead to abandonment of the entire colony (Keedwell 2005; O'Donnell et al. 2010).

Reduced water flows, invasive plants and introduced 
predators are interacting threats that put further pressure on black-fronted tern populations. For example, lower river flows stabilise islands and increase channelisation, facilitating alien plant species encroachment and establishment, as well as increasing mammalian access to areas where black-fronted terns nest (Hicks et al. 2008; Pickerell 2015; Brummer et al. 2016). Furthermore, introduced vegetation provides habitat and cover for mammals (Norbury \& Heyward 2008; Pickerell 2015). Effective methods for improving environmental conditions for black-fronted terns are needed (O'Donnell et al. 2016). However, these multiple threats, combined with colonial nesting with variable site fidelity of black-fronted terns, pose a significant challenge for conservation managers seeking to improve the nesting success of black-fronted terns, and reverse their population declines.

Conservation management of black-fronted terns has focused mostly on large-scale or localised control of introduced mammalian predators. Sustained year-round predator control on a landscape level on the Tasman River has been only partly successful (Cruz et al. 2013). Localised, intensive predator control on the Ōhau River successfully protected a single site (Anderson 2014). However, this level of localised control cannot be applied to most rivers because black-fronted tern colony locations generally vary depending on the availability of habitat at different sites (Keedwell 2005; O'Donnell et al. 2016). One study on the Tekapo River (Maloney et al. 1999), and anecdotal evidence from the Eglinton and lower Waitaki Rivers, have shown that black-fronted terns respond to vegetation clearance by using the resulting bare gravel for roosting and nesting. Nevertheless, we still do not have a good understanding in New Zealand of how vegetation clearance affects nesting success of black-fronted terns (Maloney et al. 1999; O’Donnell et al. 2016). Vegetation clearance has been used in Europe, North America, and Asia to improve the nesting success of other tern species dependent on open areas for nesting (e.g. Jenniges \& Plettner 2008; Fujita et al. 2009; Tinbergen \& Heemskerk 2016).

In New Zealand, braided river islands have the potential to act as refugia for black-fronted terns as water can act as a barrier to the movement of some mammalian species for example feral cats (Pickerell 2015). Detection rates of mammals are lower on braided river islands compared to adjacent banks (Pierce 1987; Pickerell 2015), and this can lead to greater nesting success of some bird species such as black-billed gulls or banded dotterels (Charadrius bicinctus) on islands (Rebergen et al. 1998; McClellan 2009; Pickerell 2015). Pickerell (2015) modelled the probability of mammalian predators being present on islands in the Rangitata River and concluded that islands smaller than 3.5 ha, clear of vegetation, more than $20 \mathrm{~m}$ from the mainland or nearest predator source, and separated by a channel with a discharge of more than 6 $\mathrm{m}^{3} \mathrm{~s}^{-1}$ would provide the best sites for breeding bird species.

We tested whether clearing islands of vegetation improves the nesting success of black-fronted terns, particularly for lowland rivers which are the most invaded by alien plant species, but also still harbour significant breeding populations of black-fronted terns (O’Donnell \& Hoare 2011; Brummer et al. 2016; O’Donnell et al. 2016; Schlesselmann et al. 2017). Using the lower Waitaki River as a case study, we addressed the following questions: (1) Which mammalian species are present on vegetated and cleared islands, and adjacent riverbanks? (2) What is the nesting success of black-fronted terns and primary causes of nest failure? (3) Which species depredate nests? (4) Do cleared islands attract black-fronted tern breeding colonies and if so, is nesting success higher on cleared compared to vegetated islands?

\section{Methods}

\section{Study area}

The study took place on the Waitaki River, South Island,

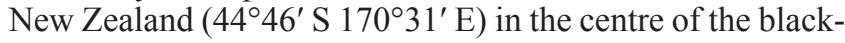
fronted tern breeding range (Schlesselmann et al. 2017). The Waitaki River is one of New Zealand's major braided rivers as well as one of the country's main sources of hydroelectric power. The $70 \mathrm{~km}$ section of the river, between the last hydroelectric dam and the sea, is called the lower Waitaki and it is braided for all but the first $5 \mathrm{~km}$ downstream of the dam (Hicks et al. 2008). The flow of the lower Waitaki River is controlled responding to energy demands, resulting in a reduced flood regime and mostly steadier river flows compared to the spikes in flow caused by spring floods and snow melt in other braided rivers (Tal et al. 2004). The lower Waitaki River is considered to be of national and international importance for braided river birds (O’Donnell \& Moore 1983; O’Donnell 2000; Forest $\&$ Bird 2016) and it holds approximately $10 \%$ of the global black-fronted tern breeding population (O'Donnell \& Hoare 2011). Invasive woody weed species, such as gorse (Ulex europoeus), Scotch broom (Cytisus scoparius), blackberry (Rubus fruticosus agg.), sweet briar (Rosa rubiginosa) and willow (Salix spp.), as well as annuals such as lupins (Lupinus polyphyllus and L. arboreus), sweet clover (Melilotus albus) and Californian poppy (Eschscholzia californica) dominate the vegetation on the riverbed. Herbicide spraying of approximately 300 ha sections of the river in the central braidplain is carried out annually by Environment Canterbury (P. Eddy, pers. comm.). The central braidplain of the Waitaki River has nevertheless reduced in width from approximately $2 \mathrm{~km}$ prior to the construction of dams in 1935 to approximately $0.5 \mathrm{~km}$ (Hicks et al. 2008). No comprehensive mammal pest control is carried out, but possums (Trichosurus vulpecula) and ferrets are controlled infrequently (G. May, pers. comm.). This was last undertaken on the northern bank of the lower Waitaki River between March and June 2016.

In this study, monitoring of predators and breeding of black-fronted terns occurred on a $15 \mathrm{~km}$ stretch of river from $1 \mathrm{~km}$ upstream of the SH 83 Kurow Bridge to the confluence of the Penticotico Stream on the true left of the Waitaki River (Fig. 1). Data were collected throughout the breeding season of black-fronted terns (October-January) in two phases: a pilot study before vegetation clearance occurred (2015/16), followed by a more extensive study post-vegetation clearance on islands (2016/17). Seven islands were cleared of all vegetation in April and May 2016 using a 2006 Komatsu D65 PX bulldozer (blade width $4 \mathrm{~m}$ ). Initial trials showed that clearing vegetation on existing islands and covering it with gravel material from that island was faster and more cost-efficient than using riverbed gravel material to build up islands. Sites were therefore chosen based on the size of preexisting islands (0.3-0.5 ha), accessibility by the bulldozer, and their height above average flow (i.e. available gravel material). Between 0.4 to 2.0 ha (average 0.94 ha) was cleared from each site (approximately $1 \mathrm{~km}$ apart). The cleared islands were built up to a height of approximately $0.5 \mathrm{~m}$ above the mean watermark to protect islands from flooding. Channels (minimum width $14 \mathrm{~m}$ ) separated each island from the adjacent riverbank or from other vegetated islands in the river. Channel 
flows around the islands were not measured and as river flow varied throughout the breeding season, discharge through channels surrounding those islands varied also.

\section{Mammalian predator monitoring}

We surveyed the presence of mammalian predators at two sites each on the southern and northern banks, with each site being about 10 to $12 \mathrm{~km}$ apart or separated by the main channel of the Waitaki River. The sites were representative of the river margins dominated by introduced woody vegetation and were selected partly based on their accessibility. At each site, a $0.8 \mathrm{~km}$ transect consisting of five large tracking tunnels (that allowed entry by predators as large as cats) was established at $200 \mathrm{~m}$ intervals parallel to the river (distance to the river between 19 and $280 \mathrm{~m}$ with an average of $124 \mathrm{~m}$ ) (following Pickerell et al. 2014). Transects were placed in vegetation to maximise the chance of predator detection (Cameron et al. 2005; Recio et al. 2010, 2013). Each tunnel was checked and re-baited with fresh rabbit (Oryctolagus cuniculus) meat every 10 days for a total of 70 days per tern breeding season.

We also monitored the presence of mammalian predators on 13 vegetated islands in both seasons and on seven islands after they were cleared in 2016/17. One tracking tunnel was placed on each island. As islands were generally small (range: 0.18-4.75 ha, average: $1.70 \mathrm{ha}$ ), it was assumed that apart from mice (Mus musculus) any mammal on the island would encounter the device (King 2005). Distance to the nearest riverbank ranged between 32 and $270 \mathrm{~m}$ (average of $91 \mathrm{~m}$ ) for the vegetated islands and between 20 and $47 \mathrm{~m}$ (average of $36 \mathrm{~m}$ ) for cleared islands. Depending on the water flow, islands could be connected to other vegetated islands on the river, but never to the banks of the river. We checked and re-baited each tracking tunnel with fresh rabbit meat every $12-15$ days (average of 13.75 days) on vegetated islands in the 2015/16 season, and every 5-10 days (average of 7.25 days) for vegetated and cleared islands in the 2016/17 season. As access to islands was limited by jet boat availability, intervals between monitoring differed slightly between years.

Footprints on tracking cards were identified to species level where possible. Because ferret, stoat and weasel (Mustela nivalis) footprints overlap in size depending on sex and age of animals (Ratz 1997), we classified all of these footprints as mustelids. We calculated mean tracking rates over the entire period that the tracking tunnels were used, and minimum and maximum tracking rates of each interval between checks of tracking tunnels.

\section{Monitoring of breeding colonies and determining causes of nest failure}

Each season, systematic searches for black-fronted tern colonies were carried out by observing birds either from the riverbanks or from on the river using a jetboat. Once a colony was located, systematic searches for nests were carried out. All nests were marked with a small rock cairn (10-15 cm tall) approximately $1 \mathrm{~m}$ upstream of the nest. We searched for additional nests from the second visit onwards;

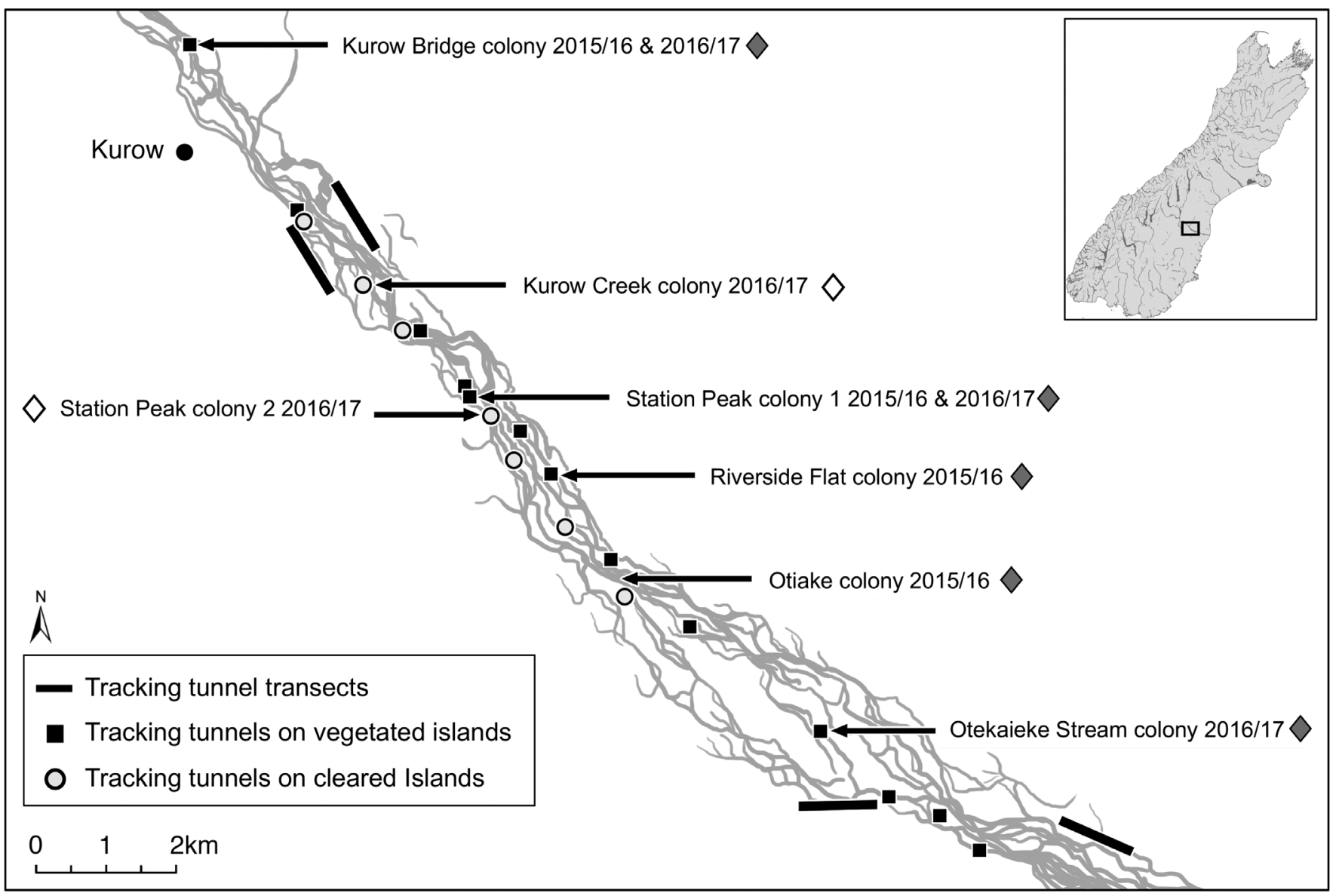

Figure 1. Study area on the lower Waitaki River, South Island, New Zealand. Locations of tracking tunnels and black-fronted tern colonies for the 2015/16 and 2016/17 breeding seasons are shown. Diamond symbols after the location name and breeding season indicate whether it was on a cleared (white) or vegetated (grey) island. 
however, only 30 nests were monitored at a time per colony to minimise disturbance and stress to breeding birds. The status of the nests was assessed by regular walk-through checks on islands at the same intervals as tracking tunnel checks. In addition, remote cameras (Ltl Acorn Ltl-5310) were used in the $2016 / 17$ breeding season to determine the identity of the predator in case of nest failure due to predation. Between two and seven cameras were set up simultaneously in a colony (colony-size dependent) with the aim of at least $20 \%$ of the walk-through monitored nests being additionally monitored with a camera. Cameras were spread throughout the colony to increase the chance of capturing predation events if they occurred, but no other criteria were used in choosing nests to monitor with a camera. Cameras were attached to a wooden stand with a small solar panel at the top of the stand (Ltl Acorn Ltl-Sun Solar Charger) and placed 1.5-2.0 m from the nest at a height of $0.3 \mathrm{~m}$, ensuring that nest contents were clearly visible. All cameras were motion-triggered and either took still photographs or short 10-30 s videos and were set to operate 24 hours per day. Memory cards were changed during each visit and cameras moved if chicks had hatched and left the immediate vicinity of the nest or the nest had failed. Camera footage showed that incubating adults returned to the nest within $5 \mathrm{~min}$ of researchers leaving the colony.

Nest outcomes were classified into the following categories: (1) Successful - if one or more eggs hatched and at least one chick was observed in or close to the nest bowl (black-fronted tern chicks are precocial and leave their nest, which is why fledging success is difficult to measure accurately); (2) Failed due to predation - no adults were present as the nest was approached, the nest bowl was either empty or contained damaged eggs, and no sign of chicks was observed; (3) Failed due to flooding-high watermark, flattened vegetation or didymo (Didymosphenia geminata) fragments around the nests and/or discoloured eggs; (4) Failed due to desertion - nest was unattended and eggs were cold; and (5) Unknown - nest outcome was unclear.

\section{Statistical analyses}

To assess the influence of vegetation clearance and island creation on nest success rates, we calculated the probability of success of nests in colonies on vegetated and newly cleared islands in 2016/17. We limited our analysis to the incubation and egg-laying periods using three different methods. We first used logistic regression of apparent hatching success (AHS), which treats each nesting attempt as a Bernoulli trial with nest fate being the response variable $(1=$ success, i.e. at least one egg hatched; $0=$ failure). When birds are nesting on islands and in colonies, where nests are highly detectable and mortality events can often be catastrophic, AHS is more accurate as it has no assumption about the rate of mortality of nests (Johnson \& Shaffer 1990). However, as it is possible to miss early-stage nesting attempts by observational monitoring, AHS can lead to a bias in estimating hatching success (Mayfield 1961, 1975). Therefore, we also used a logistic regression of conditional hatching success (CHS) and a logistic-exposure model(Log-Exp; Shaffer 2004). Both latter methods treat each observation interval as a Bernoulli trial with the response being the number of successful observation intervals at a nest $(1=$ nest survived, $0=$ nest failed) and the number of Bernoulli trials being equal to the number of observation intervals. In this way, hatching success is adjusted for nests which have been found at a later stage and were exposed to less risk of failing during the observation period compared to early-stage nests.
If all nests are found at the same stage early in the incubation period and it is possible to also find inactive nests, AHS will be as accurate as CHS and Log-Exp.

The conditional hatching success method is 'conditional' on when the monitoring commenced and only compares the risk of failure that was observed, whereas Log-Exp also takes into account that the probability of surviving an interval is dependent on the interval length (Shaffer 2004). The logisticexposure model is equivalent to other logistic regression Mayfield estimators (e.g. Aebischer 1999; Dinsmore et al. 2002), but has the advantage that it does not assume the daily survival rate is constant. If a nest succeeded or failed between nest visits, and we could not determine the exact date through camera footage, we assumed that the nest was active for half of that interval (mid-way assumption; Mayfield 1961). As visitation rates varied in this study between 5 and 10 days, this assumption can lead to some bias and the method works best with short visitation rates (Shaffer 2004).

Variation in hatching success using the different methods was explored with generalised linear mixed models (GLMMs) with a binomial error term and a logit link (for the AHS and CHS approaches) or logistic-exposure link containing an exponent $1 / t$ with $t$ being the number of observation days for each interval (for the Log-Exp approach) and with different combinations of Colony Size (to accommodate potential survival benefits of nests of larger colonies as a result of diluted predation risk and communal antipredator defence), Timing (to accommodate seasonal variation in nest success), and Vegetation (to assess the effect of clearing vegetation on nesting success) as fixed terms, and Colony (to account for the non-independence of the fate of nests within colonies) as a random term (Table 1). We decided against including Mammalian presence (to account for increased risk of failure of nests in colonies where mammals are detected) as a fixed term, as we only detected mustelids (known predators of eggs, chicks, and adult black-fronted terns) on one vegetated island with a black-fronted tern colony present twice during the breeding season (see Results), which also would be captured by the random effect.

All continuous input variables were centred and standardised following Schielzeth (2010) to compare effect sizes of variables directly. We tested for collinearity of model terms using the global model (VIF $=1.05-1.38$; Freckleton 2011). We ranked all models for each analysis using Akaike's Information Criterion corrected for small sample size $\left(\mathrm{AIC}_{C}\right.$; Burnham \&Anderson 2003). As our focus was on the particular effect of vegetation on islands, we included vegetation in all our candidate models and did not average across multiple models (Cade 2015; Banner \& Higgs 2016). All analyses were carried out in R v. 3.3.3 (R Core Team 2017).

\section{Results}

\section{Mammalian predators}

Cats, possums, hedgehogs, mustelids, and mice were detected on the banks of the lower Waitaki River in both breeding seasons, but no rats (Rattus spp.) were ever detected (Fig. 2 a, b). Possums, mustelids and mice were detected on vegetated islands, but no cats, hedgehogs or rats (Fig. 2 a, b). In both years, we detected mustelids at some point during the breeding season on about half of the vegetated islands (2015/16: 53.8\%; 2016/17:46.2\%). On cleared islands, the only species detected were mice on one island (Fig. 2b). 
Table 1. Response and explanatory variables, and model structures used in analyses of nest success probabilities of blackfronted terns on the lower Waitaki River 2016/17. The number of nests or monitoring intervals on vegetated and cleared islands in each analysis is in parentheses.

a) Apparent Hatch Success (AHS):

Model response: Successful nests (Vegetated $n=108$; Cleared $n=77$ )

Distribution (link): Binomial (logit)

\begin{tabular}{lll}
\hline Type & Variable & Explanation \\
\hline Response & Hatching success & Nest outcome (at least one egg hatched or failed) \\
Explanatory (Fixed) & Vegetation & Nest on vegetated or cleared island \\
& Timing & Day after 1 October when nest was first found \\
& Colony size & $\begin{array}{l}\text { Averaged size of colony while nest was active counting flying birds as a person } \\
\text { walked through the colony during each monitoring visit }\end{array}$ \\
& Colony & Colony identity of nest \\
\hline
\end{tabular}

b) Conditional Hatch Success (CHS):

Model response: Successful nest intervals (Vegetated $n=347$; Cleared $n=216$ )

Distribution (link): Binomial (logit)

\begin{tabular}{lll}
\hline Type & Variable & Explanation \\
\hline Response & Hatching success & Nest survival (active/at least one egg hatched or failed) \\
Explanatory (Fixed) & Vegetation & As for AHS \\
& Colony size & $\begin{array}{l}\text { Timing Day after 1 October when nest was first found or day of subsequent check } \\
\text { Size ofony at each monitoring visit counting flying birds as a person walked } \\
\text { through the colony }\end{array}$ \\
Explanatory (Random) & Colony & As for AHS \\
\hline
\end{tabular}

c) Logistic-Exposure (Log-Exp):

Model response: Successful nest intervals (Vegetated $n=240$; Cleared $n=136$ )

Distribution (link): Binomial (Logistic-exposure)

\begin{tabular}{lll}
\hline Type & Variable & Explanation \\
\hline Response & Hatching success & As for CHS \\
Explanatory (Fixed) & Vegetation & As for AHS and CHS \\
& Timing & As for CHS \\
& Colony size & As for CHS \\
Explanatory (Random) & Colony & As for AHS and CHS \\
\hline
\end{tabular}

\section{Nesting success and causes of failure}

In 2015/16, we monitored 78 nests in four colonies on four vegetated islands. In 2016/17, we monitored 108 nests in three colonies on three vegetated islands, and 77 nests in three colonies on three cleared islands (two colonies established at the Kurow Creek site independently, Fig. 1). In both years, about half of the nests hatched at least one chick (Table 2, Table S1). The main reason for nest failure in both seasons was predation, followed by flooding and desertion (Table 2). In 2016/17, most nest successes occurred in October and November, while later in the breeding season (December) almost all nests failed primarily due to predation (Fig. 3a).

\section{Identity of nest predators}

A total of 56 nests $(30.3 \%$ of total nests and $37.2 \%$ of nests per colony) was monitored with remote cameras in addition to the walk-through nest checks in 2016/17 (Table 3). Eighteen of these nests were successful and 32 nests were depredated, primarily by an avian predator $(\mathrm{n}=20)$, the southern blackbacked gull (Table 3, Fig. 3b, c and 4). Predation by southern black-backed gulls occurred throughout daylight hours and although black-fronted terns were often observed mobbing the intruder, they were unable to deter the much larger species. The ten nests for which the predator identity could not be confirmed at videoed nests were probably also preyed upon by southern black-backed gulls as all failures occurred in December in colonies where all other nests failed due to southern blackbacked gull predation. Only one predation event by a stoat was observed in late December, where the stoat killed the incubating adult at night (1:45 a.m. New Zealand Standard Time), but did not prey upon the eggs. The nest was deserted by the partner the next morning. Again, of the camera-monitored nests on cleared islands $(\mathrm{n}=24)$ and on vegetated islands ( $=32$ ), most successes were observed early in the season and most failures, and particularly predation events, late in the season (Fig. 3b, c).

\section{Comparison of nesting success between cleared and vegetated islands}

Black-fronted terns used cleared islands for breeding, roosting and feeding in the season immediately following island creation. Three breeding colonies established on two cleared islands and none of these islands were used while they were vegetated in the previous season (Fig. 1).

All models of nesting success were reasonably congruent (Fig. 5). Nesting success probability did not differ between vegetated and cleared islands as confidence intervals for Vegetation included zero in all models (Fig. 5). However, a 


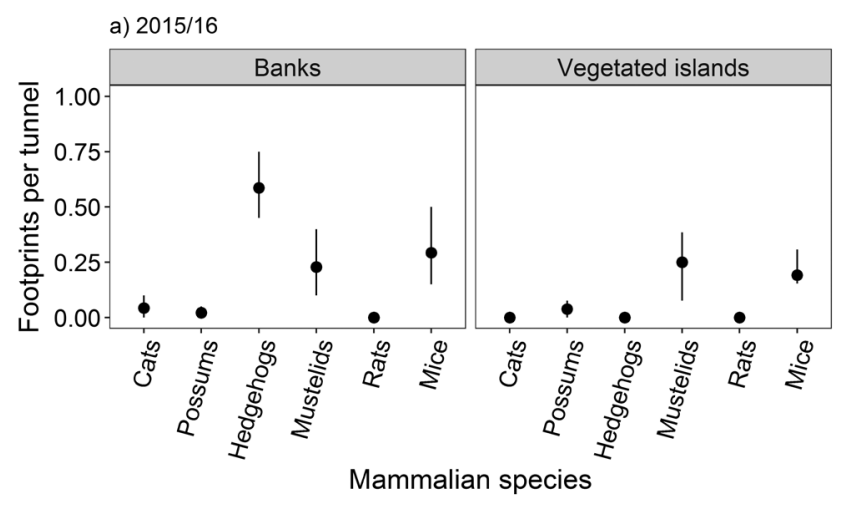

Figure 2. Mean tracking rates (footprints per tunnel, circle) and minimum and maximum tracking rates (lines) per time period of mammalian predators during the black-fronted tern breeding season of a) 2015/2016 and b) 2016/2017 on the lower Waitaki River. Banks refer to 20 tunnels in four transects operated for 70 days on the southern and northern banks of the lower Waitaki River. Vegetated islands refer to tracking tunnels operated on 13 vegetated islands for 60 days and 64 days in 2015/16 and 2016/17, respectively. Cleared islands refers to tracking tunnels operated on seven cleared islands for 59 days.

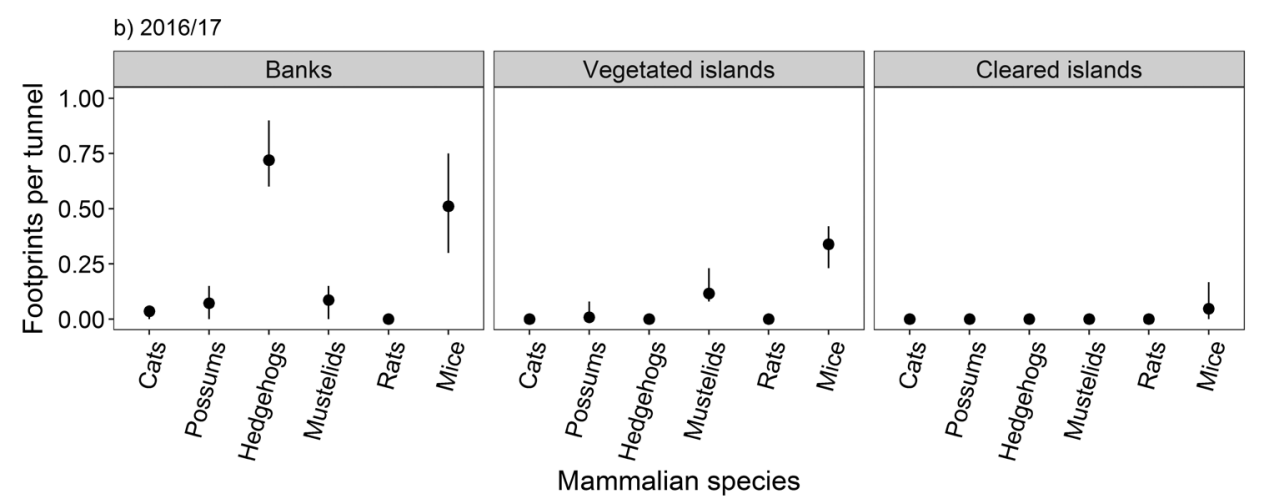

Table 2. Black-fronted tern egg survival and reasons for failed hatching on the lower Waitaki River in 2015/16 and 2016/17. Successful nests refer to nests that had at least one chick hatch. The percentage of total nests monitored is presented in parentheses.

\begin{tabular}{lcc}
\hline & $2015 / 16$ & $2016 / 17$ \\
\hline Nests monitored & 78 & 188 \\
Eggs laid & 148 & 353 \\
Successful nests & $44(56.4 \%)$ & $95(50.5 \%)$ \\
Nests failed (Total) & $31(39.7 \%)$ & $90(47.9 \%)$ \\
Nests preyed upon & $17(21.8 \%)$ & $68(36.1 \%)$ \\
Nests deserted & $2(2.6 \%)$ & $12(6.4 \%)$ \\
Nests flooded & $12(15.4 \%)$ & $4(2.1 \%)$ \\
Infertile or failed hatch & 0 & $6(3.2 \%)$ \\
Unknown outcome & $3(3.8 \%)$ & $3(1.6 \%)$ \\
Total number of nests estimated & 112 & 302 \\
\hline
\end{tabular}

slightly negative trend of vegetation on hatching success was observed using the AHS model compared to a slight positive trend in the other models. Black-fronted tern nest success probability decreased from $\sim 90 \%$ to $60 \%$ within the breeding season until the end of December (Fig. 5, 6a). In the CHS and Log-Exp model, the probability of a black-fronted tern nests being successful increased by $\sim 30 \%$ with an increased colony size, up to 200 individuals (Fig. 6b), but not in the AHS model as the confidence interval of the coefficient estimate included zero (Fig. 5).

For all methods of estimating nesting success, models including all covariates had the lowest AICc values and the highest AICc weight (Table S2). The random effect Colony identity explained zero variance (likely due to the other factors
Table 3. Outcome of black-fronted tern nests monitored with remote cameras on the lower Waitaki River in 2016/17. Successful nests refer to nests that had at least one chick hatch. The percentage of total nests monitored with cameras is presented in parentheses.

\begin{tabular}{lc}
\hline & Number of nests \\
\hline Nests monitored with cameras & 56 \\
Successful nests & $18(32.1 \%)$ \\
Nests failed (Total) & $38(67.9 \%)$ \\
Nests preyed upon by: & $32(57.1 \%)$ \\
$\quad$ southern black-backed gull $\quad 20(35.7 \%)$ \\
$\quad$ Larus dominicanus) & $1(1.8 \%)$ \\
$\quad$ black-billed gull (Larus bulleri) & $1(1.8 \%)$ \\
$\quad$ stoat (Mustela erminea) & $10(17.9 \%)$ \\
Flooded & $1(1.8 \%)$ \\
Infertile & $3(5.4 \%)$ \\
Deserted (cause unknown) & $2(3.6 \%)$ \\
\hline
\end{tabular}

capturing the majority of differences between colonies) in the case of AHS, but explained 0.097 and 0.172 variance (logit) in the CHS and Log-Exp model, respectively (Table S2).

\section{Discussion}

We detected seven mammalian predator species on the lower Waitaki River apart from rats. Most importantly, in both seasons we detected mustelids on over half of the vegetated islands, but none on cleared islands. The nesting success of black-fronted terns was low in both years with predation being the primary cause of failure. Surprisingly, video cameras showed that the primary predators of black-fronted tern nests were southern 
a) Both island types (Walk-through and camera monitored nests)

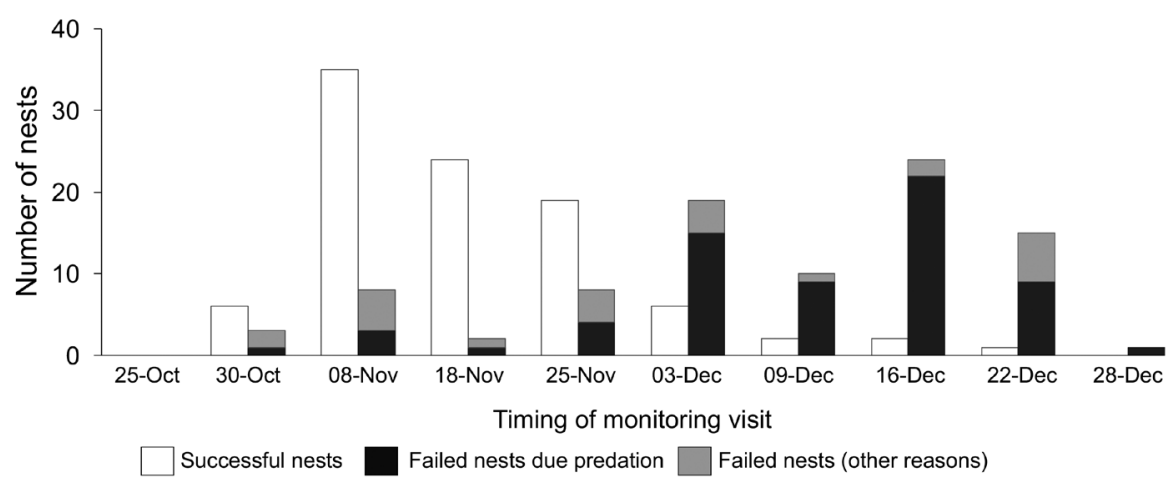

b) Cleared islands (Camera monitored nests)

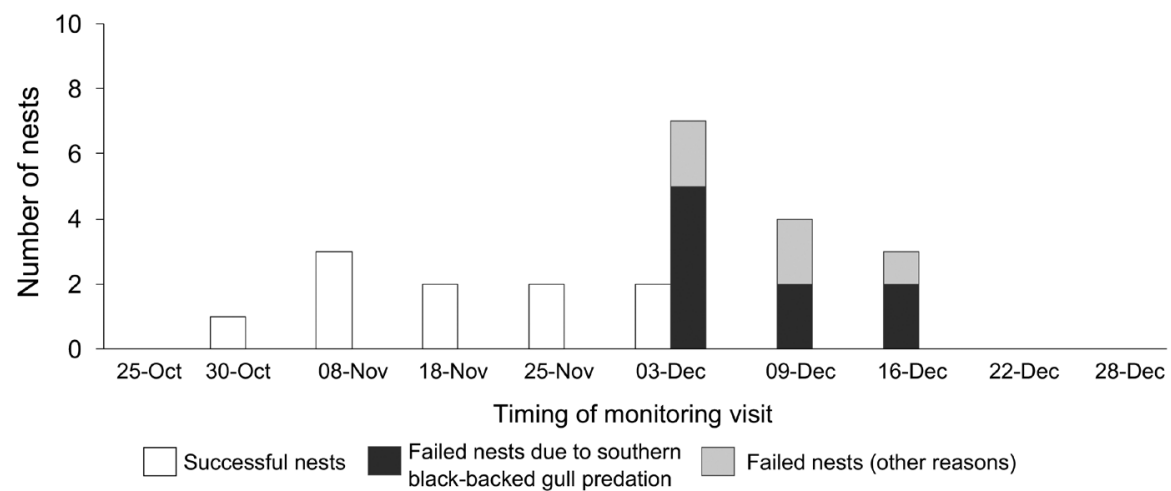

c) Vegetated islands (Camera monitored nests)

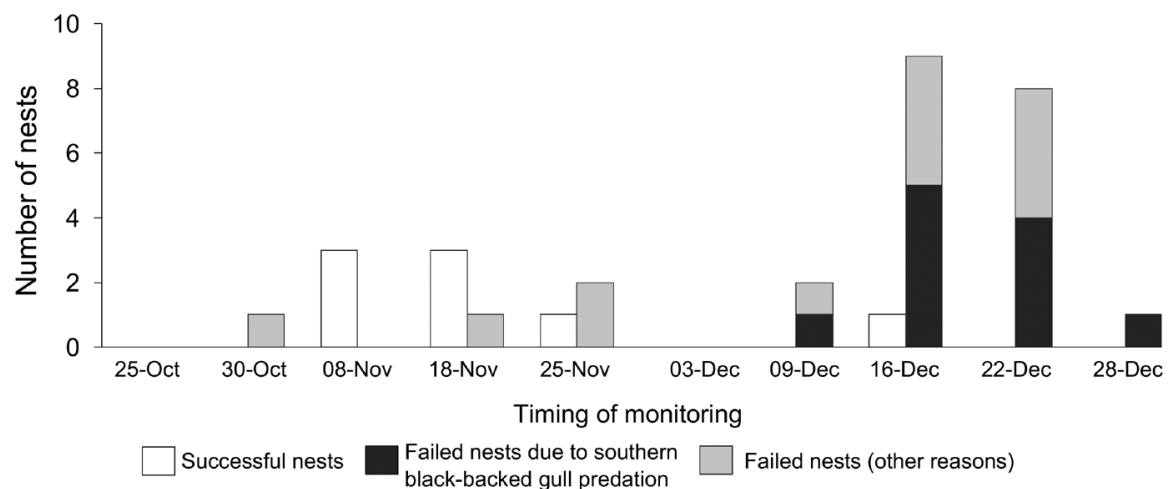

Figure 3. Timeline of outcomes ofblackfronted tern nests monitored on the lower Waitaki River in 2016/17 on a) both island types monitored by cameras and walkthrough checks $(n=185), b)$ cleared islands monitored with cameras $(\mathrm{n}=$ 24), and c) vegetated islands monitored with cameras $(\mathrm{n}=32)$. Successful nests are nests that hatched at least one chick. Other reasons for failure (see Table 2) include desertion, flooding, infertility, and in case of b) and c) predation by an unidentified predator or stoat (see Table 3). black-backed gulls rather than mammals. Black-fronted terns did establish three breeding colonies on cleared islands immediately after their creation, but nesting success did not differ between vegetated and cleared islands.

Consistent with other studies of mammalian predators in braided rivers, we detected fewer mammalian species and far fewer occurrences on islands compared to riverbanks, and even fewer mammalian predators on cleared islands compared to vegetated ones (Pierce 1987; Pickerell 2015). This was despite cleared islands being closer on average to the riverbanks where more mammals occurred (Fig. 2). On vegetated islands, mammalian predators can either be visitors or residents depending on the size of the island and availability of food sources year-round (Pickerell 2015). In our study, mustelids were often detected only once on a vegetated island, potentially indicating visiting individuals, particularly given the very good swimming abilities of stoats (King et al. 2014). Use of vegetated islands by mustelids poses a threat to black-fronted tern colonies on vegetated islands. Although these results are limited to the lower Waitaki River, and to one breeding season after clearing islands, they indicate that clearing islands is potentially useful for indirectly managing mammals in larger, lowland river systems, but further research using video cameras as well as tracking tunnels would be required to increase our understanding of detecting cryptic species in open environments (Smith \& Weston 2017).

This is the first study where the nesting success of blackfronted terns and causes of nest failure were investigated in a lowland river and nesting success of colonies on cleared and vegetated islands was compared. Overall, we found hatching success to be similarly low as in the upper river systems and nest failure mostly caused by predation (Keedwell 2005; Cruz et al. 2013; Bell 2017). In upland rivers, mammals have been reported as the primary nest predator (Keedwell 2005; Cruz et al. 2013; Bell 2017). On the Wairau River, also a lowland river, Australasian harriers caused more than half of the 19 videoed nest failures (Steffens et al. 2012). To our surprise, although mammalian predators were present in the environment, 


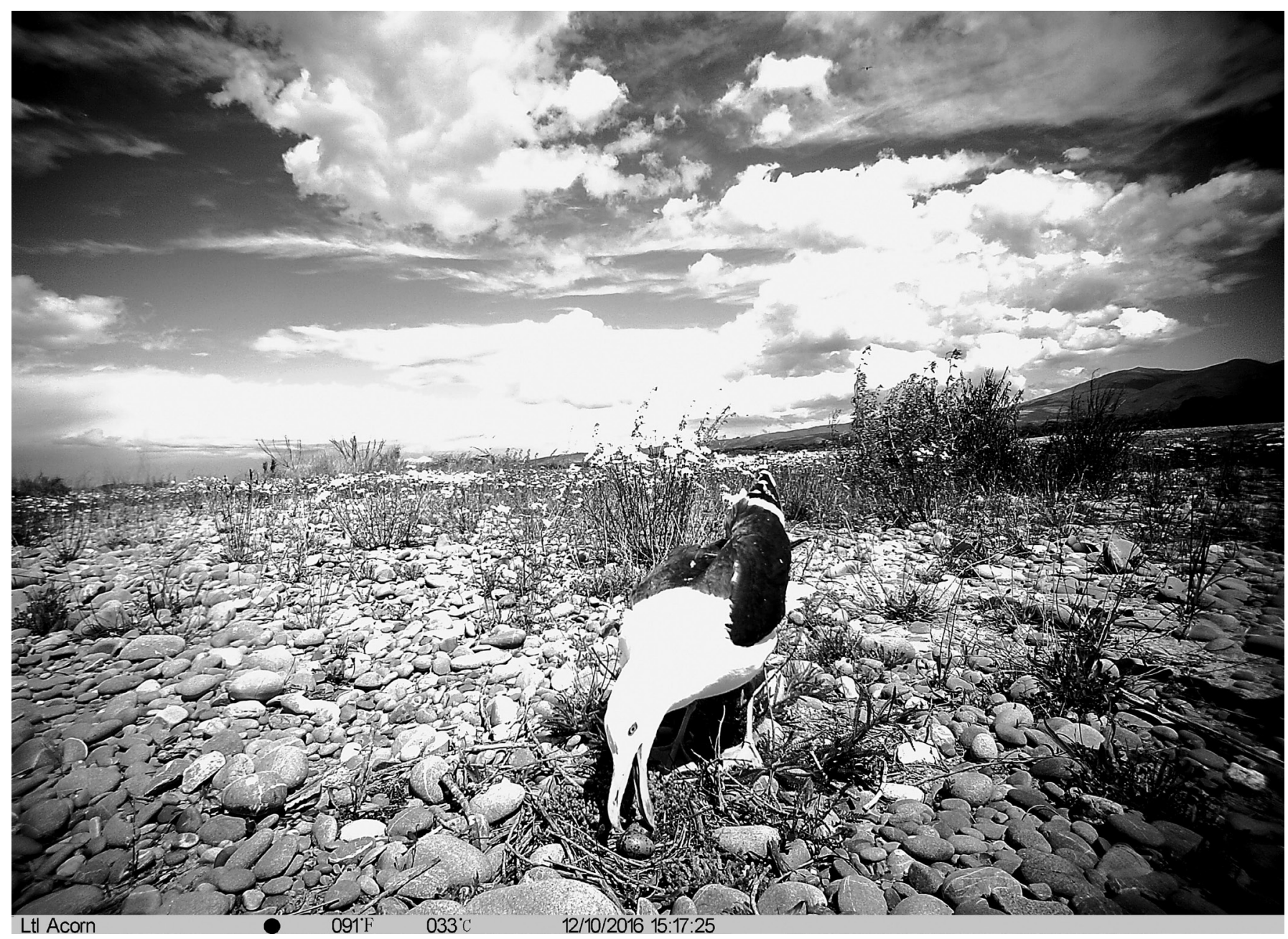

Figure 4. Southern black-backed gull captured on remote camera preying upon a black-fronted tern nest containing two eggs on the lower Waitaki River in 2016/17.

southern black-backed gulls were the major predator of nests in the lower Waitaki River rather than mammals. Native avian predators are able to prey upon eggs and chicks of braided river birds (Sanders \& Maloney 2002). In other parts of the world, specifically the impact of large gulls (Larus spp.) on tern productivity has been documented (e.g. Becker 1995; Devault et al. 2005; Donehower et al. 2007).

The decline in nesting success later in the season is most likely explained by the sudden rise in predation by southern black-backed gulls in December. A similar pattern (although involved a different predator species) has been recorded in the upper Clarence catchment and for other tern species (Arnold et al. 2004; Bell 2017). For most bird species, it is thought that early breeding results in higher reproductive success due to potentially more or higher quality resources (e.g. more available breeding habitat, lower predation pressure, more feeding territories) being available early in the season, and birds in higher body condition and with more breeding experience nesting earlier (Perrins 1996; Price et al.1988). We also found that black-fronted tern nests in larger colonies on the lower Waitaki River had a higher probability of being successful. This colony size effect has also been reported for black-fronted terns nesting on the upper Clarence River, but not from the Mackenzie Basin (Keedwell 2005; Bell 2017). Larger breeding colonies can provide protection against aerial predators in other tern species elsewhere in the world (Hernández-Matías et al. 2003). A size or density effect has also been reported for two other New Zealand braided river specialists. Breeding success of black-billed gulls increased in larger colonies and banded dotterel nests at higher density have higher nest survival (Norbury \& Heyward 2008; McClellan 2009). This might also be the case for black-fronted terns, but we currently do not know if the increase in predation by southern black-backed gulls late in the breeding season is related to the tern breeding cycle (e.g. targeting chicks, or colonies of smaller size, less experienced breeders later in the season), the gull breeding cycle (e.g. energy demands of chicks), and if it is the specialisation by one or a few gulls or the whole colony (Yorio \& Quintana 1995; Guillemette \& Brousseau 2001; Donehower et al. 2007). Predation occurred on both island types equally. In comparison to mammalian predators, southern black-backed gulls are not dependent on vegetation for cover and it is therefore not surprising that vegetation clearance had no effect.

Each of the different nest success estimators have some bias. While AHS enables comparison to other studies (Keedwell 2005; Bell 2017), it provides an overly simplistic model of hatching success. The other two estimators are based on an unbalanced sample of nest observations from vegetated and cleared islands. For example, while AHS indicated a slight 


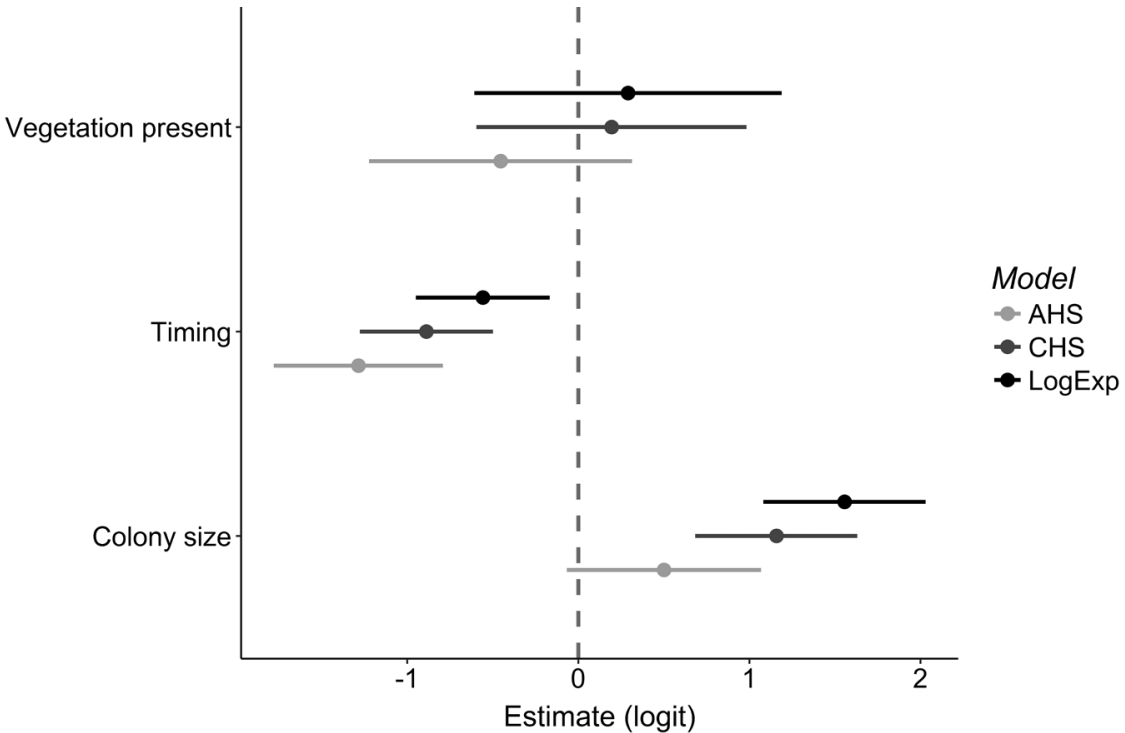

Figure 5. Coefficient estimates with $95 \%$ confidence intervals for binomial models of apparent hatching success (AHS), conditional hatching success (CHS) and logistic-exposure (Log-Exp) scaled hatching success of blackfronted tern nests on the lower Waitaki River in 2016/17.

a)

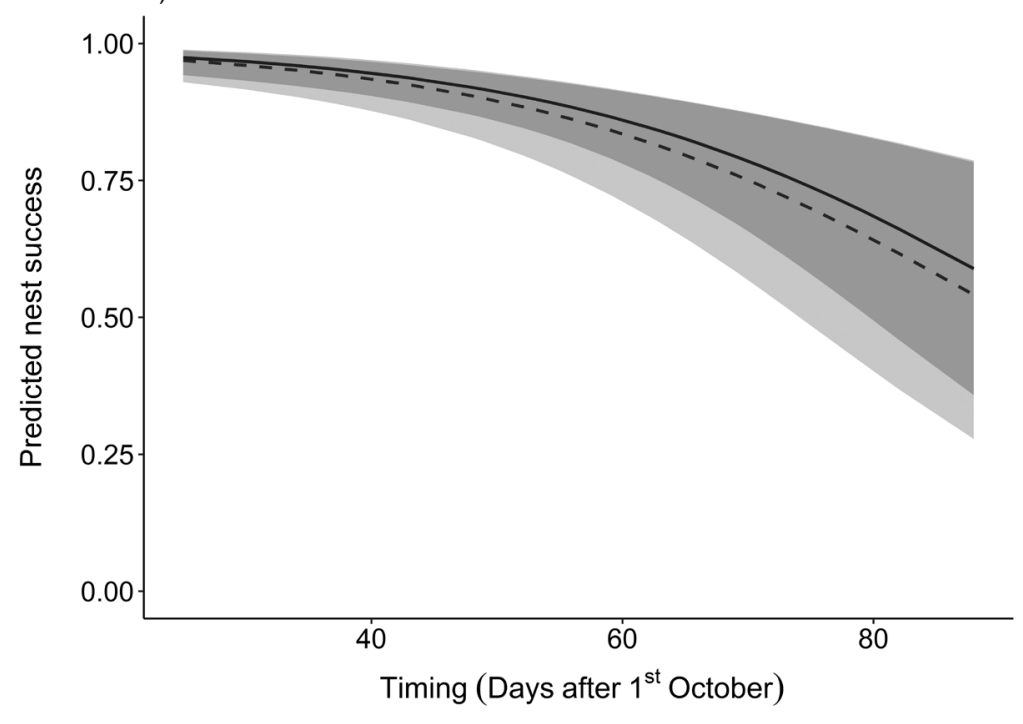

Figure 6. Average marginal predicted probability of black-fronted tern nesting success using estimates of the CHS model on the lower Waitaki River (i.e. nest having at least one egg hatch) on vegetated islands (solid blue line with shaded $95 \%$ confidence interval) and on cleared islands (dashed red line with shaded 95\% confidence interval) in relation to a) time of the season the nest was active and b) colony size.

b)

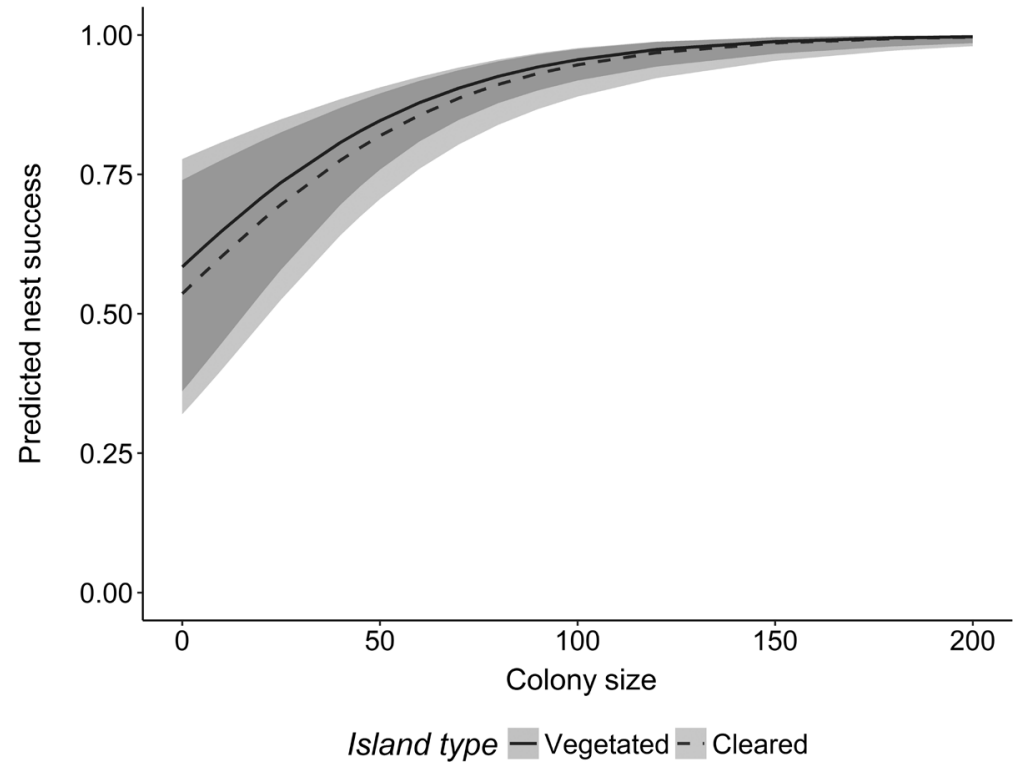


trend for vegetation clearance being beneficial for hatching success, the opposite was observed for the other two estimates. This is most likely an artefact due to only limited data being available from cleared islands as the first chicks were observed hatching in the large colony on a cleared island within a week of monitoring. Our study would have benefitted from more monitoring visits, particularly earlier in the season and recording hatching success of all nests of colonies would have provided a more balanced sample of both nesting habitats. Our access to colonies depended on the availability of a jetboat and we aimed to minimise disturbance within a breeding colony limiting our monitoring to a sample to 30 nests at a time. Advances in technology, particularly video cameras with increased memory capacity, will aid in overcoming these challenges and trade-offs between collecting data and disturbance involved in monitoring black-fronted terns, particularly on large, lowland rivers. The actual estimate of productivity (number offledglings per nest) for the lower Waitaki River will be substantially lower than the hatching success as a high degree of mortality occurs pre- and post-fledging (Keedwell 2003, 2005; Cruz et al. 2013). Nevertheless we add critical information on the hatching success of colonies in a lowland river where a large proportion of black-fronted terns breed. Different pressures are at play in lowland compared to upland rivers such as the degree of weed invasion and different impacts of predator species (Williams \& Wiser 2004; O’Donnell \& Hoare 2011; Steffens et al. 2012). Future studies should aim to estimate productivity, so that this information is also available from a lowland river environment.

In summary, this study provides further evidence that the conservation concern over this species is warranted (O'Donnell et al. 2016; Robertson et al. 2017; Wright 2017). It documents the large impact of a native avian predator on black-fronted tern nesting success on the lower Waitaki River and highlights the different impacts of predators affecting black-fronted tern colonies in lowland versus high-country rivers. Cleared islands are readily used by black-fronted terns for roosting, feeding and breeding. We present some evidence that cleared islands can provide habitat that is safe from flooding and have lower mammalian predation pressure. Artificially creating habitat to mimic natural habitat can play a critical role in population recovery of terns (Schippers et al. 2009; Pakanen et al. 2014). We recommend that the possible effects of avian predators and potential specialisation be considered (Sanz-Aguilar et al. 2009) and monitoring of black-fronted terns on lowland rivers be continued, extending it to include different life-stages, on cleared and vegetated islands.

\section{Acknowledgements}

The authors thank Paul Eddy, Brad Edwards, Jamie Cooper, Richard Maloney, Andrew Philpott, Georgina Pickerell, Bruce Scarlett, Sanjay Thakur, and Tom Waterhouse for discussions on the ground and help with work in the river. Our thanks also go to Georgina Pickerell and Craig Gillies for assisting with the identification of footprints. Tim Jowett and Matt Schofield provided statistical advice. Ken Miller assisted with the drawing of some figures. Grant Norbury, S. James Reynolds, Sanjay Thakur, and one anonymous reviewer gave helpful comments on earlier versions of this manuscript. The research was undertaken in consultation with Te Rūnanga o Ngāi Tahu and was funded by Environment Canterbury
Immediate Steps programme, the Department of Conservation and the University of Otago.

\section{References}

Aebischer NJ 1999. Multi-way comparisons and generalized linear models of nest success: Extensions of the Mayfield method. Bird Study 46: 22-31.

Anderson SJ 2014. Upper Ōhau black-fronted tern predatorcontrol project. Operational report March 2012 - Febuary 2013. Project River Recovery Report 2012/02. Twizel, Department of Conservation. $40 \mathrm{p}$.

Arnold JM, Hatch JJ, Nisbet ICT 2004. Seasonal declines in reproductive success of the common tern Sterna hirundo: timing or parental quality? Journal of Avian Biology 35: 33-45.

Banner KM, Higgs MD 2016. Considerations for assessing model averaging of regression coefficients. Ecological Applications 27: 1-16.

Becker PH 1995. Effects of coloniality on gull predation on common tern (Sterna hirundo) chicks. Colonial Waterbirds 18: $11-22$.

Bell M 2017. Population size, breeding success and predators of black-fronted tern (Chlidonias albostriatus) in the Upper Clarence River catchment, New Zealand. Notornis 64: 154-161.

BirdLife International 2017. The IUCN Red List of Threatened Species 2016. http://www.iucnredlist.org [accessed 11 December 2017].

BrummerTJ, ByromAE, Sullivan JJ, HulmePE2016. Alien and native plant richness and abundance respond to different environmental drivers across multiple gravel floodplain ecosystems. Diversity and Distributions 22: 823-835.

Burnham KP, Anderson DR 2003. Model selection and multi-model inference: a practical information-theoretic approach. 2nd edn. New York, Springer Science and Busines Media. 488 p.

Cade B 2015. Model averaging and muddled multimodal inferences. Ecology 96: 2370-2382.

Cameron BG, van Heezik Y, Maloney RF, Seddon PJ, Harraway JA 2005. Improving predator capture rates: Analysis of river margin trap site data in the Waitaki Basin, New Zealand. New Zealand Journal of Ecology 29: 117-128.

Cruz J, Pech RP, Seddon PJ, Cleland S, Nelson D, Sanders MD, Maloney RF 2013. Species-specific responses by ground-nesting Charadriiformes to invasive predators and river flows in the braided Tasman River of New Zealand. Biological Conservation 167: 363-370.

Devault TL, Douglas MB, Castrale JS, Charles E, Hayes T, Rhodes Jr. OE 2005. Identification of nest predators at a least tern colony in southwestern Indiana. Waterbirds 28: 445-449.

Dinsmore SJ, White GC, KnopfFL 2002. Advanced techniques for modeling avian nest survival. Ecology 83:3476-3488.

Donehower CE, Bird DM, Hall CS, Kress W 2007. Effects of gull predation and predator control on tern nesting success at Eastern Egg Rock, Maine. Waterbirds 30: 29-39.

Forest \& Bird 2016. New Zealand seabirds: Sites on land - rivers, estuaries, coastal lagoons \& harbours. Wellington, The Royal Forest \& Bird Protection Society of New Zealand. 176 p.

Freckleton RP 2011. Dealing with collinearity in behavioural 
and ecological data: Model averaging and the problems of measurement error. Behavioral Ecology and Sociobiology 65: 91-101.

Fujita G, Totsu K, Shibata E, Matsuoka Y, Morita H, Kitamura W, Kuramoto N, Masuda N, Higuchi H 2009. Habitat management of little terns in Japan's highly developed landscape. Biological Conservation 142: 1891-1898.

Guillemette M, Brousseau P 2001. Does culling predatory gulls enhance the productivity of breeding common terns? Journal of Applied Ecology 38: 1-8.

Hernández-Matías A, Jover L, Ruiz X 2003. Predation on common tern eggs in relation to sub-colony size, nest aggregation and breeding synchrony. Waterbirds 26: 280-289.

Hicks DM, Duncan MJ, Lane SN, Tal M, Westaway R 2008. Contemporary morphological change in braided gravelbed rivers: new developments from field and laboratory studies, with particular reference to the influence of riparian vegetation. In: Habersack HM, Piégay H, Rinaldi M eds. Gravel-bed rivers VI: From process to understanding to river restoration. Pp. 557-586.

Higgins PJ, Davies SJJF eds. 1996. Handbook of Australian, New Zealand \& Antarctic birds. Volume 3: Snipe to pigeons. 2nd ed. Melbourne: Oxford University Press. Pp. 699-708.

Jenniges JJ, Plettner RG 2008. Least tern nesting at human created habitats in central Nebraska. Waterbirds 31: 274-282.

Johnson DH, Shaffer TL 1990. Estimating nest success: when Mayfield wins. The Auk 107: 595-600.

Keedwell RJ 2003. Does fledging equal success? Post-fledging mortality in the black-fronted tern. Journal of Field Ornithology 74: 217-221.

Keedwell RJ 2005. Breeding biology of black-fronted terns (Sterna albostriata) and the effects of predation. Emu 105: 39-47.

Keedwell RJ, Sanders MD, Alley M, Twentyman C 2002. Causes of mortality of black-fronted terns Sterna albostriata on the Ohau River, South Island, New Zealand. Pacific Conservation Biology 8: 170-176.

King CM 2005. The handbook of New Zealand mammals. Melbourne, Oxford University Press. 610 p.

King CM, Veale A, Patty B, Hayward L 2014. Swimming capabilities of stoats and the threat to inshore sanctuaries. Biological Invasions 16: 987-995.

Maloney RF, Keedwell RJ, Wells NJ, Rebergen AL, Nilsson RJ 1999. Effect of willow removal on habitat use by five birds of braided rivers, Mackenzie Basin, New Zealand. New Zealand Journal of Ecology 23: 53-60.

Mayfield HF 1961. Nesting success calculated from exposure. The Wilson Bulletin 73: 255-261.

Mayfield HF 1975. Suggestions for calculating nest success. The Wilson Bulletin 87: 456-466.

McClellan RK 2009. The ecology and management of Southland's black-billed gulls. Unpublished $\mathrm{PhD}$ thesis, University of Otago, Dunedin, New Zealand. 264 p.

Ministry for the Environment \& Stats NZ2017. New Zealand's Environmental Reporting Series: Our Fresh Water 2017. Wellington, Ministry for the Environment \& Stats NZ.98 p.

Norbury G, Heyward R 2008. Predictors of clutch predation of a globally significant avifauna in New Zealand's braided river ecosystems. Animal Conservation 11: 17-25.

O'Donnell CFJ 2000. The significance of river and open water habitats for indigenous birds in Canterbury, New Zealand.
Christchurch, Environment Canterbury Report U00/37. $74 \mathrm{p}$.

O’Donnell CFJ, Hoare JM 2011. Meta-analysis of status and trends in breeding populations of black-fronted terns (Chlidonias albostriatus) 1962-2008. New Zealand Journal of Ecology 35: 30-43.

O'Donnell CFJ, Moore SGM 1983. The wildlife and conservation of braided river systems in Canterbury. Fauna Survey Report 33. Wellington, New Zealand Wildlife Service, Department of Internal Affairs. 73 p.

O’Donnell CFJ, Sedgeley JA, van Hal J 2010. Variation in house cat (Felis catus) predation sign at a black-fronted tern (Sterna albostriata) colony. Notornis 57: 43-47.

O’Donnell CFJ, Sanders M, Woolmore C, Maloney RF 2016. Management and research priorities for conserving biodiversity on New Zealand's braided rivers. Wellington, Department of Conservation. $46 \mathrm{p}$.

Pakanen V-M, Hongell H, Aikio S, Koivula K 2014. Little tern breeding success in artificial and natural habitats: modelling population growth under uncertain vital rates. Population Ecology 56: 581-591.

Perrins CM 1996. Eggs, egg formation and the timing of breeding. Ibis 138: 2-15.

Pickerell, GA 2015. Braided-river islands as refuges from introduced mammalian predators: characteristics influencing predator presence, and consequences of reduced flow. Unpublished $\mathrm{PhD}$ thesis, University of Otago, Dunedin. 271 p.

Pickerell GA, O’Donnell CFJ, Wilson DJ, Seddon PJ 2014. How can we detect introduced mammalian predators in non-forest habitats? A comparison of techniques. New Zealand Journal of Ecology 38: 86-102.

Pierce RJ 1987. Predators in the Mackenzie Basin: their diet, population dynamics, and impact on birds in relation to the abundance and availability of their main prey (rabbits). Unpublished report. Wellington, Department of Conservation. $109 \mathrm{p}$.

Price T, Kirkpatrick M, Arnold SJ 1988. Directional selection and the evolution of breeding date in birds. Science 240: 798-799.

R Core Team 2017. R: A Language and environment for statistical computing. Vienna. R foundation for statistical computing. https://www.r-project.org/.

Ratz H 1997. Identification of footprints of some small mammals. Mammalia 61: 431-441.

Recio MR, Mathieu R, Maloney R, Seddon PJ 2010. First results of feral cats (Felis catus) monitored with GPS collars in New Zealand. New Zealand Journal of Ecology 34: 288-296.

Recio MR, Mathieu R, Latham MC, Latham ADM, Seddon PJ 2013. Quantifying fine-scale resource selection by introduced European hedgehogs (Erinaceus europaeus) in ecologically sensitive areas. Biological Invasions 15: 1807-1818.

Robertson HA, Baird KA, Dowding JE, Elliott GP, Hitchmough RA, Miskelly CM, McArthur N, O’Donnell CFJ, Sagar PM, Scofield RP, Taylor GA 2017. Conservation status of New Zealand birds, 2016. New Zealand Threat Classification Series 19. Wellington, Department of Conservation. 23 p.

Sanders MD, Maloney RF 2002. Causes of mortality at nests of ground-nesting birds in the Upper Waitaki basin, South Island, New Zealand: a 5-year video study. Biological Conservation 106: 225-236. 
Sanz-Aguilar A, Martínez-Abraín, Tavecchia G, Mínguez E, Oro D 2009. Evidence-based culling of a facultative predator: efficacy and efficiency components. Biological Conservation 142: 424-431.

Schielzeth H2010. Simple means to improve the interpretability of regression coefficients. Methods in Ecology and Evolution 1: 103-113.

Schippers P, Snep RPH, Schotman AGM, Jochem R, Stienen EWM, Slim PA2009. Seabird metapopulations: searching for alternative breeding habitats. Population Ecology 51: 459-470.

Schlesselmann AKV, Cooper J, Maloney RF 2017. Single season colony records of black-fronted terns (Chlidonias albostriatus) spanning their entire breeding range. Notornis 64: $38-43$.

Shaffer TL 2004. A unified approach to analyzing nest success. The Auk 121: 526-540.

Smith DHV, Weston KA 2017. Capturing the cryptic: a comparison of detection methods for stoats (Mustela erminea) in alpine habitats. Wildlife Research 44:418-426.

Steffens KE, Sanders MD, Gleeson DM, Pullen KM, Stowe CJ 2012. Identification of predators at black-fronted tern Chlidonias albostriatus nests, using mtDNA analysis and digital video recorders. New Zealand Journal of Ecology 36: 48-55.

Tal M, Gran K, Murray AB, Paola C, Hicks DM 2004. Riparian vegetation as a primary control on channel characteristics in multi-thread rivers. In: Bennett SJ, Collinson JC, Simon A eds. Riparian vegetation and fluvial geomorphology. Water Science and Application 8, Washington DC, American Geophysical Union. Pp. 43-58.

Tinbergen JM, Heemskerk LM 2016. Local black tern Chlidonias niger population trends in relation to nest platform provisioning. Ardea 104: 239-252.

Turbott EG 1967. Buller's birds of New Zealand. Auckland, Whitcombe and Tombs.

Williams PA, Wiser S 2004. Determinants of regional and local patterns in the floras of braided riverbeds in New Zealand. Journal of Biogeography 31: 1355-1372.

Wright J 2017. Taonga of an island nation: saving New Zealand's birds. Wellington, Parliamentary Commissioner for the Environment. 117 p.

Yorio P, Quintana F 1995. Predation by kelp gulls Larus dominicanus at a mixed-species colony of royal terns Sterna maxima and cayenne terns Sterna eurygnatha in Patagonia. Ibis 139: 536-541.

Received 18 December 2017; accepted 13 April 2018

Editorial board member: Jamie Wood

\section{Supplementary Material}

Additional supporting information may be found in the online version of this article:

Appendix 1. Black-fronted tern nest survival on vegetated and cleared islands in the lower Waitaki River in 2016/17.

Appendix 2. Comparison of different models using a) apparent hatching success, b) conditional hatching success, c) logistic-exposure) to explore variation in hatching success of black-fronted terns.

The New Zealand Journal of Ecology provides online supporting information supplied by the authors where this may assist readers. Such materials are peer-reviewed and copy-edited but any issues relating to this information (other than missing files) should be addressed to the authors. 